Terr. Atmos. Ocean. Sci., Vol. 18, No. 2, I-VI, June 2007

\title{
Preface to the Special Issue on \\ Taiwan Chelungpu-Fault Drilling Project (TCDP): Site Characteristics and On-Site Measurements
}

\author{
Sheng-Rong Song, Chien-Ying Wang, Jih-Hao Hung, and Kuo-Fong Ma
}

Earthquakes induced by the seismic faulting are the most dangerous and unpredictable natural hazards known to man. A typical case was the 1999 Chi-Chi earthquake $\left(\mathrm{M}_{\mathrm{w}} 7.7\right)$, induced by faulting along the Chelungpu fault resulting in many casualties and enormous damage to property in Taiwan. The earthquake caused a total surface rupture of about $80-90 \mathrm{~km}$ along the Chelungpu fault and large vertical offsets reaching as high as $8-9 \mathrm{~m}$ (Chen et al. 2001). The rupture behavior of this earthquake was well recorded by the Taiwan Strong Motion Network ( 600 stations) and GPS (130 stations). Using the strong motion and teleseismic data, and GPS displacement, several groups of researchers have produced models of spatial distribution of slip and slip velocity for the earthquake (Johnson et al. 2001; Pathier et al. 2003; Yu et al. 2003). Common results of these studies show that slip occurred over an area of about 80 by $40 \mathrm{~km}$ with the hypocenter in the southern region and rupture propagation mainly to the north. Inverted slip distribution have correlated very well with the geological observations. Such studies show that most of the co-seismic slip is at a depth of less than $10 \mathrm{~km}$ (Ma et al. 1999; Kao and Chen 2000). A large slip of up to $12 \mathrm{~m}$ was found at the northern end of the fault near the surface (Ma et al. 2003). In the northern region of the fault where displacements are very large, the level of ground acceleration and associated building damage is relatively low. Estimates of the slip velocity show that faulting occurred very rapidly $\left(1-3 \mathrm{~m} \mathrm{sec}^{-1}\right)$ but slip was smooth producing low levels of high-frequency radiation (Wang 2006a, b). In contrast, the southern portion of the fault had much smaller displacements, but the level of accelerations was higher (Wang 2006a, b). One explanation for such very large slips was that a lubrication mechanism may have occurred during the earthquake to reducing dynamic frictional resistance (Ma et al. 2003).

An essential issue in understanding the earthquake's rupture process and mechanism is the level of stress along the fault before, during, and after the earthquake. The energy balance between tectonic stresses, dynamic friction, radiated energy, and heat dissipation controls the character of dynamic rupture. There are many hypotheses for how a fault loses strength during sliding, including normal interface vibration, acoustic fluidization, elastohydrodynamic lubrication, thermal pressurization, mechanical lubrication, silica gel lubrication and melting (McKenize and Brune 1972; Brune et al. 1993; Brodsky and Kanamori 2001; Ma et al. 2003; Di Toro et al. 2004; Wibberley and Shimamoto 2005). Physical and chemical data are essential for making progress in understanding how large earthquakes occur. The purpose of the Taiwan Chelungpu-fault Drilling Project (TCDP) is to obtain a physical sample of the fault where large displacements were known to have occurred during the Chi-Chi earthquake. Physical and chemical examinations of the fault surface should make it possible to infer important features, such as dynamic frictional characteristics. The large amount of fault slip at or near the surface provides a unique opportunity to study first-hand the physical mechanisms and 
chemical reactions involved in faulting during large earthquakes. The behavior of the thrust fault system of the Chelungpu fault during the 1999 Chi-Chi, Taiwan, earthquake presents clear advantages in the analysis of seismogenesis because the system is shallow dipping, and amenable to imaging and drilling. With this in mind, the NSC granted the TCDP funding in 2003, thereby allowing for the drilling of deep holes into the Chelungpu fault zone so as to obtain samples to shed light on the aforementioned issues. Drilling and coring at Hole-A and Hole-B with a side-track coring finished in mid-2005. In our reckoning it is now time to publish the current results of studies conducted both domestically and internationally. Hence we propose to collect the results from the site survey and on-site measurements, after going through regular peer reviewing process, as one special issue to demonstrate the recent progress in TCDP. We invited colleagues studying the geological and geophysical aspects of the Chelungpu fault to contribute their experiences and most recent works. Positive responses and a total of 11 contributions have been received from colleagues for this special issue.

Before drilling commenced in 2004, some geological investigations had already been carried out on the Plio-Pleistocene stratigraphy, sedimentology and structures of the Chelungpu fault area (Chen et al. 1999; Lin et al. 2007), as well as shallow seismic reflection stratigraphy of the central Taiwan (Wang et al. 2007). In addition, the characteristics of fault zone structures along the outcrops of surface ruptures occurring during the 1999 Chi-Chi Taiwan earthquake and 3D geometry of the Chelungpu fault have also been studied (Isaacs et al. 2007; Yang et al. 2007). Based on these results, a terrace near the Takung River of Taichung City was chosen as the drilling site. This site is some $2 \mathrm{~km}$ away from the surface rupture. The expectation was that the fault zone of the Chelungpu fault would be encountered between 900 to $1200 \mathrm{~m}$ in drilling depth (Wang et al. 2007). Two holes, named Hole-A and Hole-B with a side-track coring were drilled for the TCDP. Hole-A was sunk from the surface to a depth of $2003.26 \mathrm{~m}$ with cuttings from 0 to $431.34 \mathrm{~m}$ and cores sampled from 431.34 to $2003.26 \mathrm{~m}$ down at the end of 2004. In addition, Hole-B with a side-track branch was cored between 950 to $1350 \mathrm{~m}$ in May 2005. Several groups designed experiments on site to measure the physical and chemical properties of samples when the cores were extracted from the holes. Meanwhile, well logging data, such as FMI, temperature, electrical resistivity, density, gamma ray and Pand S-wave sonic velocity, were taken and on-site planning was conducted for different depth intervals during drilling.

During drilling, more than six examinations, including core descriptions on the lithology, stratigraphy and structures (Sone et al. 2007; Song et al. 2007; Yeh et al. 2007), on-line gas monitoring, thermal and in-situ stress measurements (Lin et al. 2007), well logging (Hung et al. 2007), nannofossils (Wu et al. 2007) and microgeobiology descriptions (Wang et al. 2007), were conducted with the results of these experiments and on-site measurements presented in this special issue. Core observations on lithology, nannofossils, structures and well loggings indicate that the three sedimentary formations of western Taiwan can be identified: the PlioPleistocene Chulan Formation, the Pliocene Chinshui Shale, and the Miocene Kueichulin Formation. In addition, at least six major fault zones can be recognized in the cores; those at depth 1111 m (FZ1111) and 1712 m (FZ1712) may correspond to the Chelungpu and Sanyi faults, respectively (Song et al. 2007; Hung et al. 2007; Wu et al. 2007). Detailed descriptions 
on the meso-structures at three shallower fault zones have been given in this issue (Sone et al. 2007). A core-based stress measurement method, anelastic strain recovery (ASR) technique was used to determine both the orientations and magnitudes of present three-dimensional principal rock stresses. Preliminary results showed that the orientation of principal stresses changed between the shallower depths above the fault and the deeper depths below; that is, present stress distribution at the TCDP site might be influenced by the Chelungpu-fault rupture (Lin et al. 2007). Samples retrieved from the drilled core ranging from 464 to $1451 \mathrm{mbls}$ were examined to characterize microbial community structures through cultivation-based approaches. The results indicate that microorganisms including fermenters, heterotrophic sulfate reducers, acetate-utilizing and $\mathrm{H}_{2}$-utilizing sulfate reducers, iron reducers and methanogens were ubiquitously present in the core samples. These results infer that the foreland sedimentary strata disturbed by tectonic activities over a geological time scale might support a heterotrophydominated deep terrestrial subsurface microbial ecosystem (Wang et al. 2007).

Finally, we dedicate this special issue to the National Science Council (NSC) of Taiwan, Republic of China for its continued financial support in making this project successful. We are grateful to all participants of the TCDP including: drilling-company technicians, colleagues from several universities in Taiwan and Japan as well as the JAMSTEC, and students and assistants from NCU and NTU. We would also like to thank the International Continental Scientific Drilling Program (ICDP) for providing technical consulting, and partial funding.

\section{REFERENCES}

Brodsky, E. E., and H. Kanamori, 2001: Elastohydrodynamic lubrication of faults. J. Geophys. Res., 106, 16367-16374.

Brune, J. N., S. Brown, and P. A. Johnson, 1993: Rupture mechanism and interface separation in foam rubber models of earthquakes: A possible solution to the heat flow paradox and the paradox of large overthrusts. Tectonophysics, 218, 59-67.

Chen, W. S., C. H. Erh, M. M. Chen, C. C. Yang, I. S. Chang, T. K. Liu, and C. S. Horng, 1999: The evolution of Foreland Basins in the western Taiwan: evidence from the PlioPleistocence sequences. Bull. Centr. Geol. Surv., 13, 137-156. (in Chinese)

Chen, Y. G., W. S. Chen, J. C. Lee, Y. H. Lee, C. T. Lee, H. C. Chang, and C. H. Lo, 2001: Surface rupture of 1999 Chi-Chi earthquake yields insights on active tectonics of central Taiwan. Bull. Seismol. Soc. Am., 91, 977-985.

Di Toro, G., D. L. Golbsby, and T. E. Tullis, 2004: Friction falls toward zero in quartz rock as slip velocity approaches seismic rates. Nature, 427, 436-439.

Hung, J. H., Y. H. Wu, E. C. Yeh, J. C. Wu, and TCDP Scientific Party, 2007: Subsurface structure, physical properties, and fault zone characteristics in the scientific drill holes of Taiwan Chelungpu-fault Drilling Project. Terr. Atmos. Ocean. Sci., 18, 271-293, doi: 10.3319/TAO.2007.18.2.271(TCDP).

Isaacs, A. J., J. P. Evans, S. R. Song, and P. T. Kolesar, 2007: Structural, mineralogical, and geochemical characterization of the Chelungpu thrust fault, Taiwan. Terr. Atmos. Ocean. Sci., 18, 183-221, doi: 10.3319/TAO.2007.18.2.183(TCDP). 
Johnson, S., Y. J. Hsu, P. Segall, and S. B. Yu, 2001: Fault geometry and slip distribution of the 1999 Chi-Chi, Taiwan earthquake imaged from inversion of GPS data. Geophy. Res. Lett., 28, 2285-2288.

Kao, H., and W. P. Chen, 2000: The Chi-Chi earthquake sequence: active out-of-sequence thrust faulting in Taiwan. Science, 288, 2346-2349.

Ma, K. F., C. T. Lee, Y. B. Tsai, T. C. Shin, and J. Mori, 1999: The Chi-Chi Taiwan earthquake: large surface displacement on an island thrust fault. EOS, 80, 605-611.

Ma, K. F., J. Mori, S. J. Lee, and S. B. Yu, 2001: Spatial and temporal distribution of slip for the 1999 Chi-Chi, Taiwan, earthquake. Bull. Seismol. Soc. Am., 91, 1069-1087.

Ma, K. F., E. E. Brodsky, J. Mori, C. Ji, T. R. A. Song, and H. Kanamori, 2003: Evidence for fault lubrication during the 1999 Chi-Chi, Taiwan, earthquake ( $\mathrm{M}_{\mathrm{w}}$ 7.6). Geophys. Res. Lett., 30, 1244, doi: 10.1029/2002GL015380.

McKenzie, D., and J. N. Brune, 1972: Melting on fault planes during large earthquakes. Geophys. J. R. Astr. Soc., 29, 65-78.

Lin, A. T., S. M. Wang, J. H. Hung, M. S. Wu, and C. S. Liu, 2007: Lithostratigraphy of the Taiwan Chelungpu-fault Drilling Project-A borehole and its neighboring region, central Taiwan. Terr. Atmos. Ocean. Sci., 18, 223-241, doi: 10.3319/TAO.2007.18.2.223 (TCDP).

Lin, W., E. C. Yeh, H. Ito, T. Hirono, W. Soh, C. Y. Wang, K. F. Ma, J. H. Hung, and S. R. Song, 2007: Preliminary results of stress measurement using drill cores of TCDP Hole-A: an application of anelastic strain recovery method to three-dimensional in-situ stress determination. Terr. Atmos. Ocean. Sci., 18, 379-393, doi: 10.3319/TAO.2007.18.2. 379(TCDP).

Pathier, E., B. Fruneau, B. Deffontaines, J. Angelier, C. P. Chang, S. B. Yu, and C. T. Lee, 2003: Coseismic displacements of the footwall of the Chelungpu fault by the 1999, Taiwan, Chi-Chi earthquake from InSAR and GPS data. Earth Planet. Sci. Lett., 212, 73-88.

Sone, H., E. C. Yeh, T. Nakaya, J. H. Hung, K. F. Ma, C. Y. Wang, S. R. Song, and T. Shimamoto, 2007: Mesoscopic structural observations of cores from the Chelungpu Fault System, Taiwan Chelungpu-fault Drilling Project Hole-A, Taiwan. Terr. Atmos. Ocean. Sci., 18, 359-377, doi: 10.3319/TAO.2007.18.2.359(TCDP).

Song, S. R., L. W. Kuo, E. C. Yeh, C. Y. Wang, J. H. Hung, and K. F. Ma, 2007: Characteristics of the lithology, fault-related rocks and fault zone structures in TCDP Hole-A. Terr. Atmos. Ocean. Sci., 18, 243-269, doi: 10.3319/TAO.2007.18.2.243(TCDP).

Wang, C. Y., C. L. Lee, M. C. Wu, and M. L. Ger, 2007: Investigating the TCDP drill site using deep and shallow reflection seismics. Terr. Atmos. Ocean. Sci., 18, 129-141, doi: 10.3319/TAO.2007.18.2.129(TCDP).

Wang, J. H., 2006a: A review of the source parameters of the $1999 \mathrm{M}_{\mathrm{s}}$ 7.6 Chi-Chi, Taiwan, earthquake. Terr. Atmos. Ocean. Sci., 17, 179-202.

Wang, J. H., 2006b: Energy release and heat generation during the $1999 \mathrm{M}_{\mathrm{s}} 7.6$ Chi-Chi, Taiwan, earthquake. J. Geophys. Res., 111, B11312, doi:10.1029/2005JB004018.

Wang, P. L., L. H. Lin, H. T. Yu, T. W. Cheng, S. R. Song, L. W. Kuo, E. C. Yeh, W. Lin, and C. Y. Wang, 2007: Cultivation-based characterization of microbial communities asso- 
ciated with deep sedimentary rocks from Taiwan Chelungpu Drilling Project cores. Terr. Atmos. Ocean. Sci., 18, 395-412, doi: 10.3319/TAO.2007.18.2.395(TCDP).

Wibberley, C. A. J., and T. Shimamoto, 2005: Earthquake slip weakening and asperities explained by thermal pressurization. Nature, 436, 689-692.

Wu, J. C., S. T. Huang, M. H. Wang, C. C. Tsai, W. W. Mei, J. H. Hung, T. Y. Lee, K. M. Yang, and K. F. Lee, 2007: Core slabbing and nannofossil analysis on the Chelungpu fault zone, Taichung, Taiwan. Terr. Atmos. Ocean. Sci., 18, 295-325, doi: 10.3319/ TAO.2007.18.2.295(TCDP).

Yang, K. M., S. T. Huang, J. C. Wu, H. H. Ting, W. W. Mei, M. Lee, H. H. Hsu, and C. J. Lee, 2007: 3D geometry of the Chelungpu Thrust System in central Taiwan: its implications for active tectonics. Terr. Atmos. Ocean. Sci., 18, 143-181, doi: 10.3319/TAO.2007.18.2. 143(TCDP).

Yeh, E. C., H. Sone, T. Nakaya, K. H. Ian, S. R. Song, J. H. Hung, W. Lin, T. Hirono, C. Y. Wang, K. F. Ma, W. Soh, and M. Kinoshita, 2007: Core description and characteristics of fault zones from Hole-A of the Taiwan Chelungpu-fault Drilling Project. Terr. Atmos. Ocean. Sci., 18, 327-357, doi: 10.3319/TAO.2007.18.2.327(TCDP).

Yu, S. B., Y. J. Hsu, L. C. Kuo, H. Y. Chen, and C. C. Liu, 2003: GPS measurement of postseismic deformation following the 1999 Chi-Chi, Taiwan, earthquake. J. Geophys. Res., 108, 2520, doi: 10.1029/2003JB002396.

Song, S. R., C. Y. Wang, J. H. Hung, and K. F. Ma, 2007: Preface to the special issue on Taiwan Chelungpu-fault Drilling Project (TCDP): Site Characteristics and on-site measurements. Terr. Atmos. Ocean. Sci., 18, I-VI, doi: 10.3319/TAO.2007.18.2.I (TCDP). 


\section{Responsible Editor:}

Louis Suh-Yui Teng

Department of Geosciences, National Taiwan University

E-mail: tengls@ntu.edu.tw

\section{Guest Editors:}

Chien-Ying Wang

Department of Earth Sciences and Institute of Geophysics, National Central University

E-mail:wangcy@cc.ncu.edu.tw

Kuo-Fang Ma

Department of Earth Sciences and Institute of Geophysics, National Central University

E-mail: fong@earth.ncu.edu.tw

Jih-Hao Hung

Department of Earth Sciences and Institute of Geophysics, National Central University

E-mail: jhhung@ncu.edu.tw

\section{Executive Guest Editor:}

Sheng-Rong Song

Department of Geosciences, National Taiwan University

E-mail:srsong@ntu.edu.tw 